\title{
原著 4
}

\section{原発性痛風と慢性関節リウマチの合併は、はたして negative association か? 自験例による検討}

松本美富士 難波 大夫

\section{要 約}

痛風，慢性関節リウマチ（RA）ともに比較的 頻度の高いリウマチ性疾患であるにあかかわらず, 従来加ら両疾患の合併はむしろ稀であり，相互に negative associationの関係にあるとされていた. そこで, 自験症例から原発性痛風1,123例,RA597 例のなかで両疾患の診断基準を満たす症例がそれ ぞれ 4 例， 1 例の計 5 例存在した。これらは臨床 的に両疾患合併，併発之診断された。この 5 例は 単純疫学的期待值 $(1 \sim 4$ 人) 以上に存在してい た．両疾患の合併は従来考えられていたより，決 して稀でないことを示しており，両疾患の合併の 確診に従来のような厳格さを必要とするはか疑問 である。リウマチ性疾患に関する最近の進歩を背 景に, 新しい視点から両疾患の合併についての検 討が期待される。

\section{緒言}

原発性痛風抒よび慢性関節リウマチ（RA）は いずれも比較的頻度の高いリウマチ性疾患である 1，2）。しかしながら，両疾患の合併，併発の報告 は予想よりもはるかに少なく，痛風とRAは相互 にnegative associationの関係にあると考えられ ていた ${ }^{3 \sim 5)}$

一方, 最近の痛風, RAの病態に関する知見の 進歩により，簡便かつ精度の高い診断が早期から 可能となり，従来とは状況は異なってきている. すなわち，両疾患の合併の診断に必ずしも従来の ような厳格さが必要かは疑問であり，両疾患の合
併が真に稀であるか否かを改めて検討する必要が ある，そこで，自験痛風ならびにRA症例から両 疾患の合併について解析を行った，その結果，両 疾患の合併は従来から言われていたほど，必ずし 屯稀でない結果を得た。

\section{対象と方法}

自験痛風登録症例のうち, 痛風およびRAに関 する臨床的評価が可能な原発性特発性痛風の男性 1,123 例について, 痛風発症前, ならびに発症後の 関節炎所見について解析した。調查時の平均年齢 40.8土11.2歳(24 76歳)であり, 尿酸動態からの 痛風の病型が明らかな症例では過剩産生型：混合 型 : 排泄低下型=5.7 : 2.1:2.3であった。痛風性 関節炎の診断は米国りウマチ学会 (ACR)の 1977 年分類基準 ${ }^{6)}$ によった。これら症例から ACRの RA分類基準 ${ }^{7)}$ を満足する症例を抽出し，RAの 合併の妥当性を検討した。

一方, 自験 RA 症例の597例は, 男 : 女 $=7.2$ : 2.8 , 平均年齢 $52.7 \pm 9.8$ 歳（21〜 74歳）であり, いずれあACRのRA分類基準を満足する症例であっ た.これら症例について痛風の診断基準を満足す る症例を抽出し，その診断の妥当性を検討した．

痛風, RA合併頻度の疫学的期待值の算出は, 本邦における痛風 ${ }^{8)}, \mathrm{RA}^{9)}$ の有病率が全人口の 0.3 $\sim 0.5(\mathrm{~A} \sim \mathrm{B}) \%$, 男女比は痛風が95〜99:5〜1 $(\mathrm{C} \sim \mathrm{D}: \mathrm{E} \sim \mathrm{F}), \mathrm{RA}$ が1〜3: 9〜7（G〜H : I J $)$ であるとする数值を係数として, 痛風集団 $(\mathrm{K})$ に打けるRA合併期待値 $\left(\mathrm{X}: \mathrm{X}_{1} \sim \mathrm{X}_{2}\right)$, RA集

受付：1999年 7 月21日，受理:1999年10月20日

愛知県豊川市民病院内科 Yoshifuji Matsumoto and Daio Naniwa 
団 (M) における痛風合併期待值 $\left(Y ： Y_{1} \sim Y_{2}\right)$ を単純計算した。すなわち，

$$
\begin{aligned}
& \mathrm{X}_{1}=\mathrm{K} \times(\mathrm{A} / 100) \times(\mathrm{G} /(\mathrm{G}+\mathrm{I})), \\
& \mathrm{X}_{2}=\mathrm{K} \times(\mathrm{B} / 100) \times(\mathrm{H} /(\mathrm{H}+\mathrm{J})), \\
& \mathrm{Y}_{1}=\mathrm{M} \times(\mathrm{A} / 100) \times(\mathrm{D} /(\mathrm{D}+\mathrm{F})), \\
& \mathrm{Y}_{2}=\mathrm{M} \times(\mathrm{B} / 100) \times(\mathrm{C} /(\mathrm{C}+\mathrm{E})) \\
& \text { により計算した. }
\end{aligned}
$$

\section{結 果}

1）特異な経過を呈した痛風，RA合併症例

症例は60歳, 男性, 警備員（表 1 の症例 2 ）. 主 訴は多発性関節痛である，既往歴に特記すべきも のはないが，家族歷に従姉妹にRA患者が存在す る. 現病歴は1982年に右第一中足趾関節に発作性 の関節痛が出現し, 局所の腫脹, 発赤を伴ってい たが, 数日で軽快し, 放置していた, その後, 半年

\begin{tabular}{|c|c|c|c|c|c|}
\hline & 症例 1 & 症例 2 & 症例 3 & 症例 4 & 症例 5 \\
\hline 診断時年齢 & 65歳 & 60歳 & 54歳 & 48歳 & 74歳 \\
\hline 性 別 & 男 & 男 & 男 & 男 & 男 \\
\hline 発症時期 & 1975年 & 1982年 & 1982年 & 1990年 & 1977年 \\
\hline 初発症状 & 単関節痛 & 単関節痛 & 多関節痛 & 単関節痛 & 単関節痛 \\
\hline 先行疾患 & 痛風 & 痛風 & RA & 痛風 & 痛風 \\
\hline 発症間隔 & 10年 & 3年 & 1年 & 3年 & 19.7年 \\
\hline $\begin{array}{c}\text { 血清尿酸値 } \\
\text { (診断時) }\end{array}$ & $10.8 \mathrm{mg} / \mathrm{dl}$ & $10.8 \mathrm{mg} / \mathrm{dl}$ & $9.6 \mathrm{mg} / \mathrm{dl}$ & $9.2 \mathrm{mg} / \mathrm{dl}$ & $9.8 \mathrm{mg} / \mathrm{dl}$ \\
\hline 痛風病型 & 産生過剩 & 排泄低下 & 排泄低下 & 排泄低下 & 混合 \\
\hline $\begin{array}{l}\text { リウマトイド } \\
\text { 因子 }\end{array}$ & 陽性 & 陽性 & 陽性 & 陽性 & 陽性 \\
\hline $\begin{array}{l}\text { 痛風の経過 } \\
\text { (合併診断後) }\end{array}$ & 良好 & 良好 & 良好 & 良好 & 良好 \\
\hline $\begin{array}{l}\text { RAの経過 } \\
\text { (合併診断後) }\end{array}$ & 不良 & 不良 & 良好 & 不良 & 不良 \\
\hline $\begin{array}{l}\text { X線所見 } \\
\text { RA (stage) }\end{array}$ & III & III & III & II & II \\
\hline over-hanging & + & + & + & - & + \\
\hline 合併症 & 大動脈瘤 & 間質性肺炎 & - & - & - \\
\hline
\end{tabular}
から 1 年毎に同部に発作性の関節痛が出現してい た. 1984年 1 月には両側肩関節痛が出現. 1985年 1 月に朝のこわばりが出現し, 両膝, 足関節, 手

表 1 痛風と慢性関節リウマチ合併症例の臨床病像（自験例 5 例）

RA：慢性関節リウマチ
指関節に関節痛々腫脹を伴ったため，近医を受診 し，RAと診断された，薬物療法を受けるも軽快 しないため，1985年 6 月精査目的で当科受診となっ た。なお，1985年 1 月多発性関節痛出現以降は発 作性の右第一中足趾関節痛は出現していない.

初診時理学的所見は両側手関節, MP関節, PIP 関節，膝関節，足関節の 3 関節領域以上に左右対 称性に活動性関節炎を認めるが，耳介軟骨部，第 一中足趾関節部に結節はみられない.

臨床検査成績は検尿にて蛋白（士），沈渣にて 尿酸塩結晶は認めず, PH 5.5であった，血液学的 検査では白血球, 血小板の軽度増多を認め, 生化 学検查ではBUN 23.6mg/d1であるが,creatinine は $1.0 \mathrm{mg} / \mathrm{dl}$ であった. 尿酸值は $10.8 \mathrm{mg} / \mathrm{dl}$ と増 加しており，血清脂質成分は中性脂肪の上昇がみ られた. 赤沈の克進, CRPの増加, リウマトイド 因子陽性, RAHA x40, 抗核抗体陽性であるが, 抗DNA抗体は陰性であった。高尿酸血症に対す る尿酸動態はクレアチニンクリアランス $83.4 \mathrm{ml}$ /分と年齢相応であり, 尿酸ク リアランスは $4.5 \mathrm{ml} / \mathrm{min}$ と低 下し, 対クレアチニンクリアラ ンス比む5.4\%と低下しており， 24 時間尿中尿酸排泄量屯 $184 \mathrm{mg}$ と低下ししていた．以上ょり本 症例の高尿酸血症は排泄低下型 と診断された. X線所見は発作 性の関節炎が反復した右第一中 足趾関節部に特徵的な punched out lesion の所見（図 1) がみ られる.また, 両手関節部, PIP, $\mathrm{MP}$ 関節部に軟部組織の腫脹, 骨粗鬆症性変化がみられ，MP 関節部に micro - erosion を認 め, Steinbrocker Stage III,

Larsen分類で最大でgrade 3 に 相当する (図 2 ).

本例は排泄低下型の高尿酸血 症による発作性の単関節炎が先 行し,やがてリウマトイド因子 陽性の多発性関節炎へと変化し 


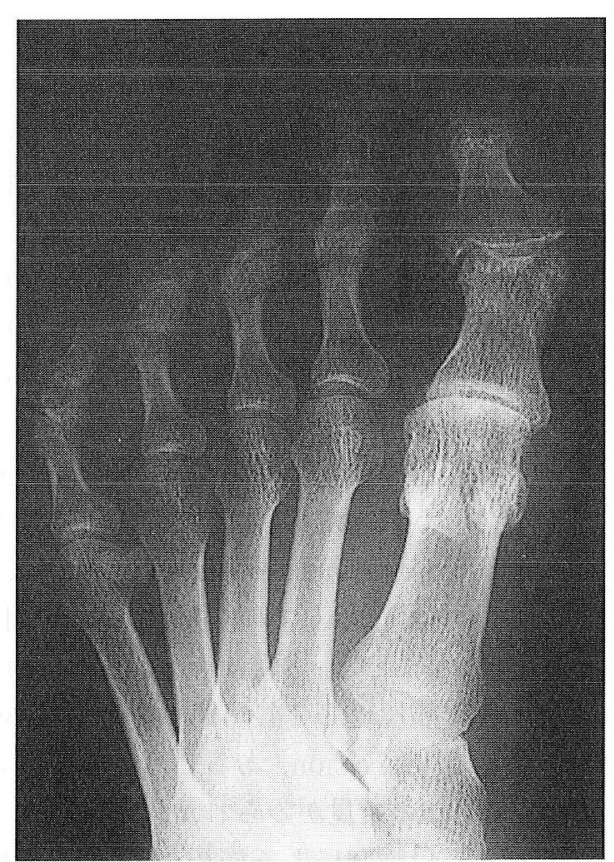

図 160 歳，男性，痛風と慢性関節リウマチ合併例の 右足部X線所見

第 1 足趾節骨外側にoverhannging像を認める

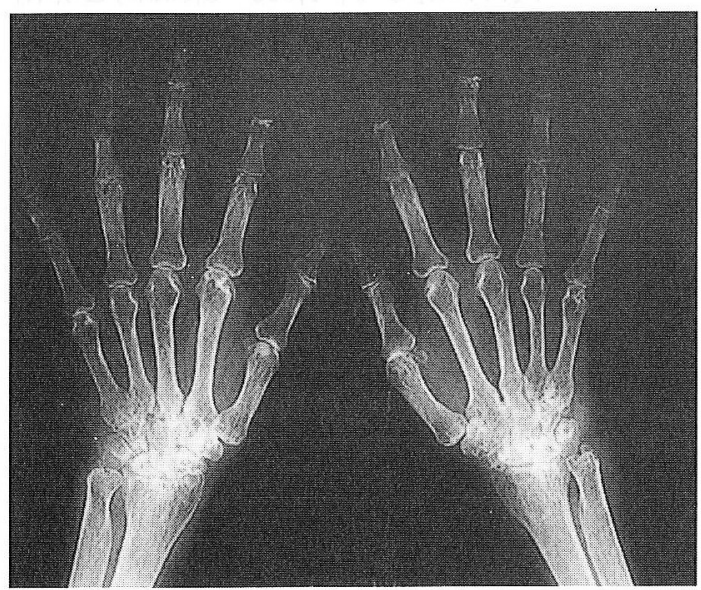

図 260 歳，男性，痛風と慢性関節リウマチ合併例の 手部 X線所見

手根骨部にはびらん性変化を認め, Stage IIIに 相当する.
ていった症例である。この関節炎をよ゙のように診 断するかであるが，単関節炎発作は痛風の ARA の1977年診断基準によると, 準拠項目の11項目中 8 項目を満たし, 痛風と診断できる.さらに, 足趾 X線上明瞭な punchedout lesionを認めたことも 経過した痛風の存在を支持する。一方，多発性関 節炎はRA分類基準の 7 項目中 5 項目を満たし， RAと分類される。

そこで, 本例を原発性痛風とRAの合併と考え， 排泄低下型高尿酸血症に対して benzbromarone, 尿アルカリ化剂を投与し，RAに対してはNSAID， 少量のステロイド薬, 抗リウマチ薬を投与した。 血清尿酸值は治療域レベルである $6 \mathrm{mg} / \mathrm{d} 1$ 前後之 安定にコントロールできたが，RAによる多発性 関節炎はコントロール不良で各種抗リウマチ薬の 工夫を行うも進行性であった.すなわち, 痛風性 関節炎が反復していた時期はRAの発症が抑えら れ，痛風のコントロールが良好となるに伴って， RAが顕著化し，持続性に活動性，コントロール 不良の経過を呈しており，痛風とRAの経過が相 互にnegative associationの経過を呈していた． さらに，1994年後半には乾性咳嗽，呼吸困難が出 現し，X線所見，胸部CT所見からRAに伴う間質 性肺炎が出現し，肺野型の悪性関節リウマチへと 進展し，現在も外来にて治療継続中である (図 3 ).

2) 痛風, RA合併症例の臨床病像

自験原発性男性痛風症例中に $4 / 1,123$ 例，自験 $\mathrm{RA}$ 症例中では $1 / 597$ 例が痛風，RAの診断基準・ 分類基準のいずれもをむ同時に満足していた。こ れら 5 例の合併症例の臨床像は表 1 のごとくであっ た. すなわち，両疾患合併の診断時年齢は $48 \sim 74$ 歳と中年以降の年齢であり，両疾患の発症間隔は 1 19.7年と症例によってさまざまであった。そ のうち 4 例は痛風が先行であり, 残り 1 例のみ RAが先行していた，両疾患合併の診断時の痛風， RAの状態，時間的関連は以下のごとくである. 症例 1 はすでに高尿酸血症の薬物療法がなされて おり，RAに伴う多発性関節炎の状態であり，症 例 2 は上記の臨床所見の記載のごとく痛風， RA が同時に存在していた. 症例 3 は比較的コントロー ルされているRAの経過中, 痛風発作の出現办ら 
表 2 痛風と慢性関節リゥマチ合併の疫学（本邦）

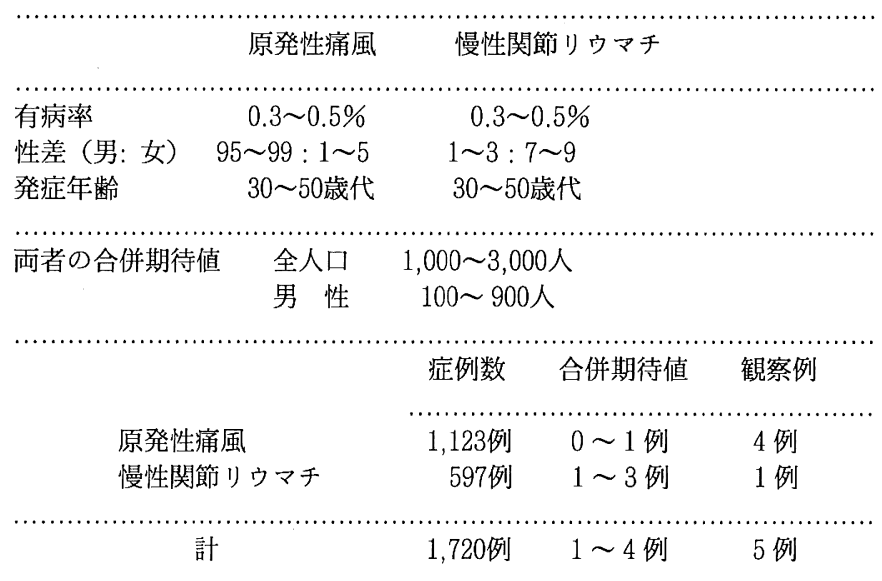

表 3 原発性痛風と慢性関節リウマチとの合併が稀な理由

\section{1. 高尿酸血症の影響}

- 免疫担当細胞の活性化，增殖反応の抑制

・リンパ球抗原認識, 感作の抑制

・抗体産生反応の抑制

・好中球ライソゾーム酵素放出，活性酸素産生抑制

2. 慢性関節リウマチの影響

・尿酸塩結晶へのリウマトイド因子結合

・リウマトイド因子による尿酸塩貪食抑制

・慢性関節リウマチ病変部への尿酸塩結晶沈着抑制

・関節液中低補体による炎症反応発生の抑制

3. その他

痛風の併発が診断されたものであり，症例 $4 ， 5$ はいずれも不適切な治療の痛風の経過中，RAを 併発したものであった，検査成績では，痛風診断 時血清尿酸值は9.2〜 $10.8 \mathrm{mg} / \mathrm{dl}$ と明らかな高尿 酸血症の病態を有し, 尿酸動態からの痛風の病型 は 3 例が排泄低下型であり，産生過剩型，混合型 はそれぞれ 1 例であった。当然のことながら全例 が両疾患合併の診断時にはリウマトイド因子が陽 性であった。

痛風としての経過は痛風の病型により選択され た尿酸コントロール薬の使用により, 容易にコン トロール可能であり, 痛風性関節炎の発症は尿酸
コントロール薬開始後早期に消失し， いずれも血清尿酸值が安定した時期 には痛風性関節炎の発症をみていな い.一方，RAの経過はRA先行例の 1 例を除いて不良であり，各種抗りウ マチ薬（DMARD）に抵抗性であり， 多発性活動性滑膜炎が持続しており, 経過とともに関節変形, 機能障害が出 現するあのがあった，1例（症例 2） は経過中に間質性肺炎を合併し，RA に伴う肺病変と診断された。また，両 疾患合併と診断された時期の関節 X線 所見はRAとしての変化は, $3 / 5$ 例は satge III, $2 / 5$ 例はstage IIであり, また痛風として4／5例に特徽的なover hanging lesion, あるいはpunched out lesionの所見がみられた。

3）自験例による痛風，RA合併頻度 の検討

本邦における痛風とRAとの合併頻 度の疫学的期待值は単純計算では全 人口に対して, 1,000 3,000例と算出 された。男性の原発性痛風患者に限る と, 100 900例の合併例の存在が推計 された. 同様に, 自験原発性特発性痛 風症例は男性症例が 1,123 例存在し， 疫学的RA合併期待值は $0 \sim 1$ 例と算 出された. 一方, 自験RA症例597例に おいて疫学的痛風合併期待值は $1 \sim 3$ 例と算出された。しかし，実際には痛風症例中 4 例のRA，RA症例中 1 例の痛風症例が存在し, 計 5 例の痛風とRAの合併症例を確認した（表 2 ）.

\section{考 察}

これまで国内外で痛風とRAの合併例は疫学的 に期待されるより，はるかに少ない症例しか報告， 確認されていなかったのが現状である年 10 24) その結果, 痛風とRAはその発症に対して, 相互 にnegative associationの関係にあると考えられ， これを裏付ける実験的成績も一部確認されている 25 28)，その内容をまとめると，大きく二つの面か 
ら考慮される。すすなち, 痛風の基礎病態である 高尿酸血症の影響であり, 他は関節へのRA病変 の存在による影響である（表 3 ）先ず, 高尿酸血 症の影響について, 高い濃度の尿酸が免疫担当細 胞の活性化，増殖反応に対して抑制的に作用する 可能性,リンパ球による抗原認識, 感作の抑制の 可能性, B細胞による抗体産生反応の抑制の可能 性 ${ }^{16 \sim 19)}$ ，あるいはRA炎症との関連で好中球ライ ソゾーム酵素の放出, 活性酸素産生の抑制の可能 性 $25,26,28,30)$ などが考えられている。 その結果, RA のような免疫反応に基づく炎症が起こりにくいこ とが推測されている。しかしながら，高尿酸血症 のこれらの効果は, 免疫反応の各断面で細胞単位 での結果であり, 高尿酸血症がマクロファージ， $\mathrm{T}, \mathrm{B}$ リンパ球，好中球のそれぞれに対してどのよ うなレベルで影響を与えるかの分子生物学的側面 はまったく不明である。

一方, 関節へのRA病変存在の影響は尿酸塩結 晶にリウマトイド因子（RF）が結合し，尿酸塩 結晶の滑膜, 好中球, マクロファージ系細胞によ

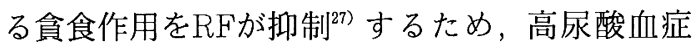
が存在し，尿酸塩結晶が形成されても，炎症性細 胞による貪食が起こりにくいため, 痛風発作が発 生し難いとか，関節滑膜にすでにRA病変が存在 する場合は滑膜への尿酸塩結晶の沈着が起こりに くいこと ${ }^{32)}$ ，RA関節液中補体の消費により，補 体の低下がみられるため, 痛風発作のような炎症 反応が起きにくい，あるいは発生しにくいなどの 機序が想定されている ${ }^{5,27,31,32)}$.

さらに, 痛風とRAが併発した場合, 両疾患の 臨床経過について興味ある現象が経験的に知られ ている，すなわち，痛風のコントロールが良好で, 血清尿酸值が低下することによって, RAの経過 が不良であることが, 臨床的観察からこれまで 確認されている ${ }^{27)}$. 両疾患の臨床経過がこのよう に逆相関することは, 両疾患の合併の negative associationをさらに支持する現象である. 今回の 自験例でもこのような症例が存在した。このよう な痛風とRAの臨床経過の逆相関の機序は不明で あるが，前述の両疾患の合併の negative associa-

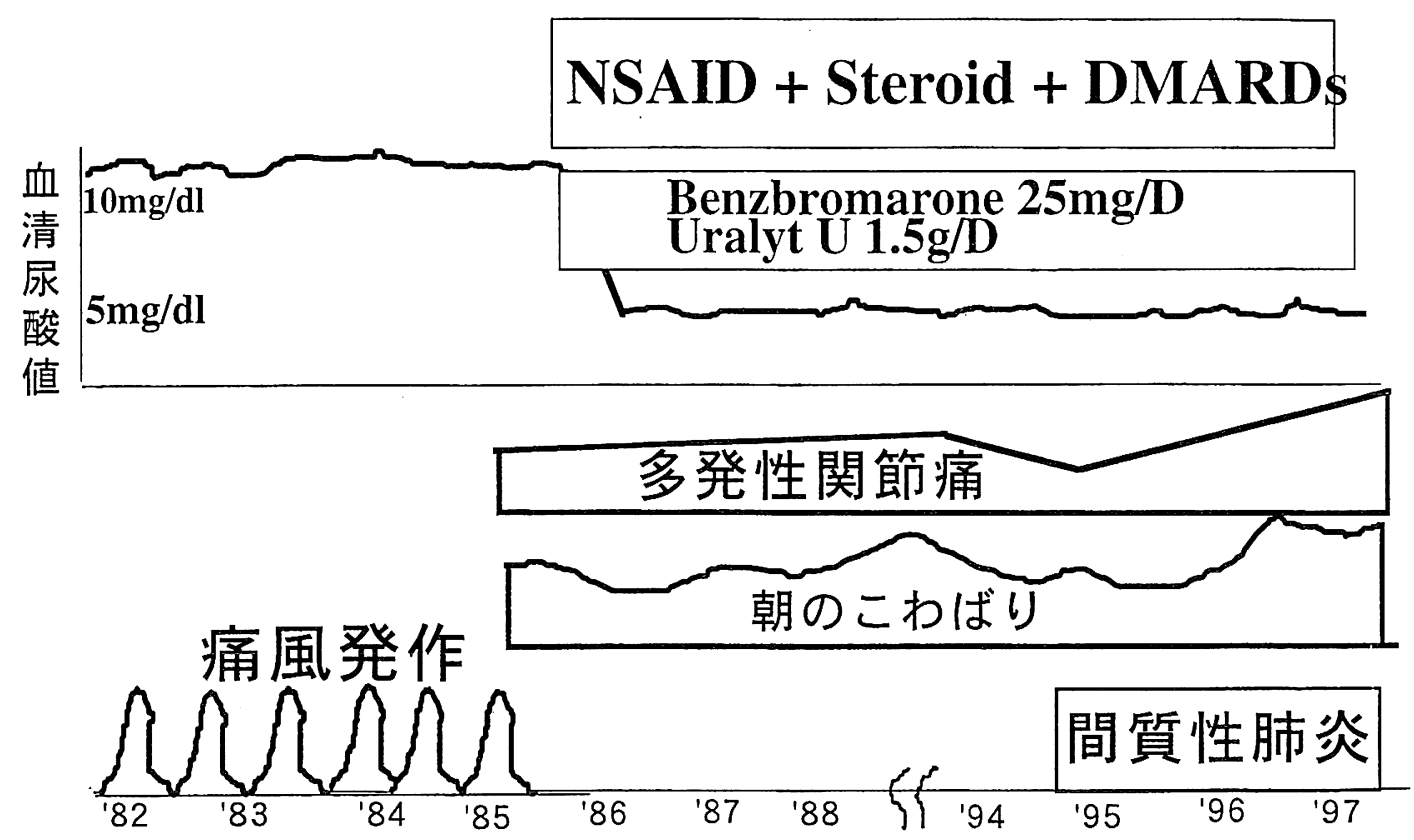

図 3 痛風, と慢性関節リウマチ合併症の臨床経過（60歳, 男性） 
tion之同様の機序で説明可能な部分もある ${ }^{5,13)}$.

これら高尿酸血症，あるいはRAの存在の影響 は一部実験的に支持する所見もあるが，直接的な 証明ではなく，推測の域をでないものもある。ま た，かなり以前に行われた研究であるあのがほと んどである. 最近のRAの病因，病態に対する分 子生物学的研究の進歩, あるいは痛風性関節炎の 分子炎症論的知見の進歩を背景にした研究が, 痛 風とRA合併との関連で行われたものはない.

痛風とRAとの合併頻度について疫学的指標か らの単純計算で, 痛風とRAの合併は本邦の全人 口に対して，1,000〜3,000例と算出される．男性 の原発性痛風患者に限ると, 100〜900例の合併例 の存在が推計される.わが国でのこれまでの両者 の合併例はこの推計数よりはるかに少ない。こ の事情は欧米症例においても同様であり, 痛風 とRAの合併は単純に疫学的推計症例数に比して はるかに少ないことより，両者は相互にnegative associationの関係にあると考えられる一つの理 由となっている。

このように痛風とRAは相互にnegative associationの関係にあって, 両者が合併することは稀で あることが国内外において繰り返し報告されてき た $\left.{ }^{4}, 5,10\right)$. しかしながら, 両者の合併が稀である とする理由は不十分であり，報告症例がただ単に， 少ないといったことも大きな影響を与えている. さらに, 痛風患者ではRF陽性率が高いとの報 告 ${ }^{13)}$ 屯あり, 両疾患の合併の確定を一層困難なむ のとしていることあ見逃せない，これまでの合併 例の報告のほとんどが，痛風結節の組織学的証明 とRAとしての滑膜組織所見の存在を必須の条件 にされてきた. はたして, 両者の合併の診断にこ のような厳格さを必要とするかは疑問である，優 秀な尿酸コントロール薬により高尿酸血症が容易 にコントロール可能であり，またRAの臨床病態 が明らかにされ，薬物療法の進歩にあ目覚ましい あのがある，さらに，RAに対してはより簡便か つ精度の高い分類基準が作られ，また早期RA診 断基準む作成されるなど，早期から比較的精度高 くRAと診断できる状況にある。このような背景 で, 痛風とRA合併例の診断に従来のような組織
学的所見が必要かについて考なければならない. 尿酸コントロール薬による安定した時期にX線 変化を伴う多発性, 慢性, 持続性関節炎を呈し, RA分類基準を満たせば，RAである可能性は極め て高い．また, RA発症後に高尿酸血症を基礎病 態として, 発作性の単関節炎を発症し, 尿酸コン トロール薬による血清尿酸值の正常化とともに， 発作性の単関節炎が消退すれば, 痛風を発症して いたと臨床的に診断し得る。このような観点で痛 風におけるRAの発症率, RAにおける痛風の合併 率が考慮されなければならない，自験例の検討は 臨床診断から両者の合併を検討したものであり， いずれの症例むその後の経過観察において両疾患 の合併の妥当性を支持するものであった.

以上のごとく，今回のわれわれの成績は両疾患 の合併は従来考えれていたほど，決してまれな病 態でないことを示している. 最近の痛風患者の増 加, 若年化などの疫学的要因が変化してきた状況 下で両者の合併について, 多施設共同によって, その実体が明らかにされることが期待される。

\section{文献}

1) Silman AJ : Epidemiology and the rheumatic diseases. In Oxford Textbook of Rheumatology 2nd ed. (edited by Maddison PJ, Isenberg DA, Woo $\mathrm{P}$ et al), Oxford Medical Publications, Oxford, 1998, p.811.

2 ) Fraser PA : Epidemiology of rheumatic diseases in selected non-European populations. In Oxford Textbook of Rheumatology 2nd ed. (edited by Maddison PJ, Isenberg DA, Woo $\mathrm{P}$ et al), Oxford Medical Publications, Oxford, 1998, p.828.

3 ）松本美富士 : 原発性痛風と慢性関節リウマチ の合併した 2 例. 東海リウマチ $18: 107-114$, 1987.

4) Yu TF : Some unusual features of gouty arthritis in females. Semin Arthritis Rheum 6 : 247-255, 1977.

5 ) Talbot JH, Altman RD, Ts'ai-Fan y: Gouty arthritis masquerading as 
rheumatoid arthritis or vice versa. Semin Arthritis Rheum 8 :77-114, 1978.

6) Wallace SL, Robinson H, Masi AT et al: Plreliminary criteria for the classification of the acute arthritis of primary gout. Arthritis Rheum $20: 895-900,1977$.

7) Arnnet FC, Edworth SM, Bloch DA et al : The American Rheumatism Association 1987 revised criteria for the classification of rheumatpid arthritis. Arthritis Rheum $31: 315-324,1988$.

8) Akizuki S:A population study of hyperuricemia and gout in Japan : analysis of sex, age and occupational diffrences in thirty-four thousand peoples living in Nagano prefecture. Ryumachi 22 : 201-209, 1981.

9) Schichikawa K, Takenaka Y, Maeda A et al : A longitadinal population survey of rheumatoid arthritis in a rural distinct in Wakayama. Ryumachi 21(suppl) : 35-43, 1981.

10) Zonana-Nacach A, Alarcon GS, Daniel WW : Rheumatoid arthritis preceding the onset of polyarticular tophaceous gout. Ann Rheum Dis 55 : 489-490, 1996.

11) Owen DS Jr, Toone E, Irby $R$ : Coexistent rheumatoid arthritis and chronic tophaceous gout. JAMA 197 : 123-126, 1966.

12) Simkin PA, Campbell FM, Larson EB : Gout in Heberden's nodes. Arthritis Rheum 20 : 895- 900, 1977.

13) Kozin F, McCarty DJ : Rheumatoid factor in the serum of gouty patients. Arthritis Rheum 20:1559-1560, 1977.

14) Schwartzberg $M$, Lieberman $D H$, Gupta VP et al : Rheumatoid arthritis and chronic gout arthropahty. JAMA 240 : 26582659, 1978.

15) Wendling $D$, Guidet $M$ : Association goutte-polyarthrite rheumatoide [Gout and rheumatoid arthritis in the same patient]. Semin Hop Paris 67 : 1497-1500, 1991.

16) Wallace DJ, Klinenberg JR, Morhaim D, et al : Coexistent gout and rheumatoid arthritis. Arthritis Rheum 22 : 81-86, 1979.

17) Lussier $A$, Medicis de $R$ : Coexistent gout and rheumatoid arthritis : a red marker ? Arthritis Rheum 22 : 939-940, 1979

18) Jessee EF, Toone E, Owen DS, et al : Coexistent rheumatoid arthritis and chronic tophaceous gout. Arthritis Rheum 23 : 244247, 1980.

19) Rizzoli AJ, Trujeque L, Bankhurst AD : The coexistence of gout and rheumatoid arthritis : case reports and a review of the literature. J Rheumatol 7 : 316-324, 1980.

20) Raman D, Abdalla AM, Newton DRL et al : Coexistence rheumatoid arthritis and tophaceous gout : a case report. Ann Rheum Dis $40: 427-429,1981$.

21) Atdjian M, Fernandez-Madrid F : Coexistence of chronic tophaceous gout and rheumatoid arthritis. J Rheumtol 8 : 989992, 1981.

22) Strader KW, Agudelo CA : Coexistent rheumatoid arthritis and gout. J Rheumatol 13 : 1307-1311, 1986.

23) Martinez-Cordero E, Bessudo-Babani A, Sandra $\mathrm{C}$ et al : Concomitant gout and rheumatoid arthritis. J Rheumatol 15 : 1307-1311, 1988.

24) Specter AK, Christman RA : Coexistent gout and rheumatoid arthritis. J Am Pediatr Med Assoc 79 : 552-558, 1989.

25) Waterworth RF : The effect of allopurinol therapy on coexistent gout and rheumatoid arthritis. Arthritis Rheum 24: 103-104, 1981.

26) Agudelo CA, Turner RA, Panetti $M$ et al : Does hyperuricemia protect from 
rheumatoid inflammation ? A clinical study. Arthritis Rheum 27 : 443-448, 1984.

27) Gorodon TP, Ahern MJ, Reid C et al : Studies on the interaction of rheumatoid factor with monosodium urate crystals and case report of coexistent tophaceous gout and rheumatoid arthritis. Ann Rheum Dis 44 : 384-389, 1985.

28) Lussier A, DeMedicis $R$ : Inhibition of adjuvant-induced arthritis in the hyperuricemia rat. SAgents Actions 8 : 536-542, 1978.

29) Ames BN, Cathcart R, Schwiers E, Hochstein $\mathrm{P}$ : Uric acid provides an antioxidant defense in humans against oxidant-and radical-caused aging and cancer : a hypothesis. Proc Natl Acad Sci USA 78 : 6858-6862, 1981.

30) Turner RA, Pisko EJ, Agudelo CA, Counts GB, Foster SL: Uric acid effects on in vitro models of rheumatoid inflammatory and autoimmune processes. Ann Rheum Dis $42: 338-342,1983$.

31) Turner RA, Counts GB, Treadway WJ, Holt DA Agudelo CA : Rheumatoid factor and monosodium urate crystla-neutrophil interactions in gouty inflammation. Inflammation $5: 353-361,1981$.

32) Schumacher HR : Pathogenesis of crystalinduced synovitis. Clin Rheum Dis 3 : 105131, 1977. 


\title{
Coexistent gout and rheumatoid arthritis: a negative association?
}

\author{
Yoshifuji Matsumoto and Taio Naniwa
}

The negative association between gout and rheumatoid arthritis (RA) is well accepted. A total of $1,000-3,000$ cases of coexistent gout and RA would be anticipated statistically in Japan. The reason for this mutual exclusion is not clear; a protective immunosuppressive effect of hyperuricemia has been included among possible explanations. To test this negative assocition, we reviewed the charts of 1,123 gouty patients and $597 \mathrm{RA}$ patients on whom clinical information was availadle. We selected those patients with clinical features of gouty arthritis and RA, fulfilling the classification criteria for gout and RA, respectively. We found 5 patiesnts fulfilling the criteria of both, and 4 of them were judged to precede gouty arthritis. A total of 0 - 3 cases of coexistent gout and RA was anticipated statistically in our rheumatology clinic. We proposed that the negative association between gout and RA must be re-evaluated in the view of clinical rheumatology and clinical epidemiology. 